\title{
Lecturer's Industrial Actions and Environmental Education Student's Academic Performance in the University of Calabar, Nigeria
}

\author{
${ }^{1}$ Eneji, Chris-Valentine Ogar ${ }^{*} \quad{ }^{2}$ Onnoghen, Nkanu Usang $\quad{ }^{3}$ Agiande, Denis Ube $\quad{ }^{4}$ Okon, Grace Maurice \\ Department of Environmental Education, Faculty of Education, University of Calabar, \\ PMB 1115, Calabar, Nigeria
}

\begin{abstract}
This study is concerned about how lecturer's industrial action affects Environmental Education student's academic performance in the University of Calabar. The study design is the survey inferential research design, the study is located in the Department of Environmental Education, University of Calabar, Nigeria. The population of the study consisted of undergraduate students, post graduate students and lecturers in the Department of Environmental Education, University of Calabar, Nigeria. A sample of two hundred and fifty respondents was selected from among undergraduate and post graduate students and lecturers in the Department of Environmental Education, University of Calabar, Nigeria. The instrument for data collection is a structured question, divided into two section, Section A is for respondent's demographic characteristics, while Section B is to elicits response based on the variables under study. The instrument was administered by the researchers and same collected back. There was $100 \%$ return rate. After coding, simple percentage was used to analyze data to answer the research questions, while Pearson Product Moment Correlation Analysis was used to test the relationship between lecturer's industrial action and Environmental Education student's academic performance in the University of Calabar. A comparison of the average scores of students was again carried out between 2013-2018, the result shows that lecturer's industrial action affects student's academic performance. The result listed some causes of lecturer's industrial action, their effects on school academic calendar and curriculum coverage and also listed the effects on student's academic performance. It was discovered that lecturer's industrial action does significantly influence Environmental Education student's academic performance negatively. It was recommended among that's that government should try as much as possible to keep to their terms of agreement with ASUU, so that they can reduce or minimize lecturer's industrial action in our university system.
\end{abstract}

Keywords: Industrial actions, academic calendar, curriculum content, student's academic performance, agreement, memorandum of understanding and memorandum of implementation, etc

DOI: $10.7176 / \mathrm{CER} / 11-7-05$

Publication date: August $31^{\text {st }} 2019$

\section{Introduction}

Globally, the university is seen and regarded as the ivory tower, a citadel of learning the fountain of intellectual development and a ground for the production of leaders of tomorrow.

The purpose for the establishment of any university is anchored on three throngs: teaching and learning, research and community services (Saharay, 2013), every university fulfills one major function, it is a knowledge and value provider, in other words, a university progresses when it is able to provide knowledge and value and when it is not properly managed by the administrators and staff, it then fails in its function of providing knowledge and value. This according to Osuorji and David, (2014) explains why merit has been the watchword in the university system - an institution in which a student must first be certified worthy in character and learning before being admitted into the Honors Degree. The tertiary institutions in Nigeria have in recent times witnessed the incessant closures of the institutions due to industrial actions by lecturers and other support staff of the universities and other tertiary institutions.

Strike action has become a recurring phenomenon and has become synonymous with University education in Nigeria. The past three decades had witnessed increased industrial action by Lecturers and this has made completing one full academic calendar unlikely (Olupayimo, 2014). The complex nature of University systems makes dispute inevitable in the university environment. Also the pursuit of incompatible goals and objectives by university management and lecturers often leads to industrial action. Lecturers in most cases may tend to seek for improved welfare while university management may desire high improved productivity from lecturers in terms of student's academic performance, attitude to work and overall job performance (Michael, 2013).

Studies have shown that the effects of these repeated closures of schools and academic programs on students' learning and their academic performances can better be imagined than described. Tertiary education in Nigeria has thus suffered tremendous setbacks as a result of industrial actions embarked upon by both members the Academic Staff Union of Universities (ASUU) and the Non Academic Staffs Unions (NASU), Senior Staff Association of Nigerian Universities (SSANU) and other micro unions in the university system. This has always subjected the 
students to pitiable conditions, disrupting their academic programs, giving students' undeserved extension in their study years, poor students' concentration on academic programs and poor lecturer-student relationships amongst others. Consequently, students' academic performance has comparatively or relatively become very poor, while various forms of examination malpractice and other social vices are on the increase (Ige, 2014; Olupayimo, 2014; Osuorji and David, 2014).

Ivancevich (2007) found that strikes actions are all organized efforts by employee to withhold work so that the employer will make greater concessions at the bargaining table. The author further opined that it is a major bargaining weapon used by labor union and it comes in different forms ranging from Economic strike where employees stop work until the demand for better condition of employment is met to sit down strike where employee strike but remain at the work place. Armstrong (2004), asserted that strike is seen as a collective organized, cessation or slowdown of work by employees, to force acceptance of their demands by the employer. The legality of the strike action however requires approval by majority of employees by ballot, independent verification to ascertain that majority support the vote and thereafter a notice is given to the employer based on decisions arrived at by employees (Ricarda, Anja, Anne and Linda, 2014).

The recurrent activities of lecturers strike have been a contending issue which although not welcomed by parents and students because of its effects on students academic performance but have been considered to be necessary in order to resuscitate the acclaimed fall in University education standard. It is incontrovertible that the agitation of academic staff unions are to foster adequate conditions of service which would go a long way in stimulating advantageous atmosphere for students to accomplish the prerequisite curriculum objectives (Saharay, 2013). This would reduce to the barest minimum half baked graduates or functional illiterates that Nigerian tertiary institutions are turning out lately. Unfortunately the strike action embarked on by lecturers whenever there is dispute between them and government always put students in detrimental conditions. The reasons for this are not farfetched, students end up having lesser period to prepare for academic exercises before examination, hence the possibility of poor academic performance normally stares at students in the face after an industrial action have been called off (Zwerling, 2008; Ayeni and Kolawole, 2014).

Studies have further shown that most often when industrial actions are embarked upon by university lecturers, their students are the ones are at the receiving end. When students study, the outcome of their studies after attending their lectures, do their assignment, write their test and finally write their examination, this outcome is ether poor or good, this is academic performance. Put in another way, student's academic performance can be described as the outcome of the studies. Academic performance is therefore the outcome of student's evaluation in the educational process indicating to what level the students have achieved the educational goals as specified in the curriculum (Edinyang and Ubi, 2013).

Student's academic performance especially in Environmental Education can be effectively harnessed under conducive learning environment and uninterrupted academic calendar, this will guarantee their academic performance. It is obvious that strike action embarked upon by lecturers in Nigeria universities, have in no small way disrupted the university academic calendar, thereby bringing about the non coverage of the university curriculum content in every course of study in the system.

Many scholars have carried various studies on strike actions and staff effectiveness in various esablishements and organization, different results were also obtained from these studies (Belot and Webbink, 2010;Baker, 2011; Altinok and Kingdon, 2012; Saharay, 2013). Most scholars say strike actions reduce productivity and diminish organizational values and worth, , others found that strike action reduces organizational goal attainments, grand the system to halt, delay in student's graduation and waiting period, makes teaching and learning clumpsy and cumbersome, makes preparation time for exams shortened (Ayeni and Kolawole, 2014 ; Edinyang and Ubi, 2013). Other effects of industrial actions also include lack or poorly covered curriculum, extension or of shortening of academic calendar (Adibe, 2009; Ige, 2014), other scholars still found that it increases economic burden on parents and guardians, lead to death and other looses (Michael, 2013; Olupayimo, 2014).

\section{Chronicle and genealogy of ASUU industrial actions}

The history of ASSU versus Federal Government strikes dates back to 1988, during the military era, when government refused the activities of ASUU and their refusal too to fund education as it is the practice in many civilized climes. Principally, the major unions found to be embarking on these industrial actions in the universities is ASUU and NASU including SSANU. Each time these industrial actions are embarked upon, it takes a very serious academic toll on the students and their academic performance. Academic Staff Union of Universities (ASUU) was established or formed as a union in the early1978; this was to replace the former Nigerian Association of University Teachers (NAUT), formed in 1965 which was an umbrella organization to protect all academic staff in Nigerian universities in the Universities of Ibadan, Nsukka, Ahmadu Bello, Zaria, Ife and Lagos. History has it that the union waxed stronger and stronger in the struggle and agitation for better condition of service, improved infrastructure among others in the early 80's, against the military regime (Adibe, 2009; Michael, 2013).

A national industrial action was organized by the union in 1988 to obtain fair wages and university autonomy. 
As a result, the ASUU was proscribed on August 7, 1988 and all its property seized. It was allowed to resume in 1990, but after another industrial action, it was again banned on August 23, 1992. However, an agreement was reached on September 3, 1992 that met several of the union's demands including the right of workers to collective bargaining. The ASUU organized further industrial actions in 1994 and 1996, protesting against the dismissal of staff by the General Sani Abacha military regime (Chisholm, 1999). The union continued its struggle for better condition of service in the universities, even after the return of democracy in 1999, demanding the right of workers against all opposition by the government of the fourth republic. This was followed by the petitioning of the authorities of the University of Illorin to Justice Mustapha Akanbi of the Independent Corrupt Practices Commission by the national president of ASUU to investigate the institution management for financial mismanagement and corruption.

ASUU had embarked on several strike action, in 2007, ASUU went on a nationwide industrial action spanning a period of three months, similarly in 2008, ASUU again went on another industrial action, which was a two weeks warning strike to press home their demands including an improved salary scheme and reinstatement of forty-nine lecturers who were dismissed from University of Ilorin in 1998. Again in 2009, June to be précised, ASUU ordered its members across the country in all universities (both federal and state universities) to embark on an indefinite strike over disagreements with the Federal Government's on an agreement it reached with the union about two and a half years ago. After three months of industrial action, in October 2009, ASUU and other staff unions signed a Memorandum of Understanding with the government and called off the industrial action (Clotfelter, Ladd and Vigdor, 2009).

Before this time, series and series of meetings have been held by ASUU leadership to review all of its activities including the memorandum signed and entered into with government. Severally, the national executive council had met from Tuesday 29th November to Thursday 1st December 2011 at the University of Port- Harcourt to review, among other things: the level of implementation of the 2009 ASUU/Government Agreement; the extent of compliance with the 2011 ASUU/FGN Memorandum of Understanding (MoU) on the implementation of the Agreement; Government's unilateral dissolution of Universities' Governing Councils; institutional accreditation and the state of the Nation, including the issue of alleged removal of fuel subsidy, but the lack of understanding between the two parties led to an indefinite strike embarked upon by the Union for fifty-nine days. It was later called off on the 1st of February, 2012. ASUU again went on a warning strike on 30th August, 2012. All these have left an unfavorable mark on the academic activities of the university students and it has also affected the academic calendar, the university curriculum coverage and the performance of the students. On 1st of July, 2013, ASUU embarked upon another Six months industrial action which was called off on the 17th of December, 2013 which really affected the Nigerian undergraduates leading to the involvement of students in many unwholesome activities (Clotfelter, Ladd and Vigdor, 2009).

Again in 2017 ASUU went on another rounds of industrial action with little or no results, government released earned academic allowance for the 2009/2010 academic session to a fraction of the university staff, with the university management in connivance with the non teaching staff sharing a larger chunk of the money leaving the university lecturers who went on the industrial action for the money with peanuts. The agitation continued with ASUU embarking on the last industrial action which began in August, 2018 and ended in December, 2018, with the federal government promising ASUU to resume payment of \#48 Billion before the $4^{\text {th }}$ of Febraury, \#20 Billion before the conduct of the presidential election and so on, unfortunately, till date, no single kobo has been received by ASUU to that effect. Yet another strike action is contemplated by ASUU. It is painful to state that often times, when ASUU embark on these incessant agitations, it usually triggers industrial action by sister associations such as NASU, SSANU etc and the resultant effects is borne more by poor parents and the students (Freier and Storck, 2012).

Many suggestions have been made as to the causes of these lecturer's industrial actions, the causes include:

\section{Staff remuneration and bonuses:}

One of the major issues bringing disunity between the lecturers and government is the issue of staff remuneration, bonuses and promotion entitlement including excess workload, which ministries and other establishment gets in form of over time or extra work load. Outside the primary purpose of teaching, lecturers teach more than 100-300 students in one lecturer room or class, the time to teach a class goes beyond the actual time the lecturer would ordinarily teach his normal class of 205-30 students. The same lecturers are also expected to mark the scripts of all these students, prepare their result, teach two or three more of such courses and also supervise the student' project. In most cases, the same routine follows all the programs in the school, from undergraduate, to Master's and $\mathrm{PhD}$ program.

Altinok and Kingdon, (2012) observe that most often, these lecturers leave their homes about 7.30 Am and return back home about 8-10 Pm daily, but in the ministry, staff are given bonuses as overtime, out of pocket expenditures, duty tour allowance and all that stuff, but university lecturers hardly get any entitlement even after performing excess work outside the usual schedule as lecturers. For example, the lecturer will teach students, take 
the students on practical's, carry them on field work, go for external examination, teaching practice and industrial work experience supervision with nothing from their employer to show appreciation for the extra work done (Kingdon, 2006).

Introduction of Treasury Single Account (TSA), The introduction of the TSA has rather affected the university system. In the university system, the cost of employing some professional are very high, while some institutions may not even have such professions, it is allowed for lecturer's to be in adjunct capacities, some lecturers may be on sabbatical, while others are on part time in another university from their original university. In situation like this, the university where these staff are doing either of Adjunct, sabbatical or part time must capture them as lecturers in that capacities, but the treasury single account came, remove some names of lecturers in the name of ghost workers without looking at the peculiarity of the condition governing the transfer of knowledge provision in another university as an adjunct staff.

Again funding the university from internally generated revenue became a problem because, universities can generate the funds, but they cannot spend them on their immediate needs except they apply and seek approval from the monitoring or approving unit before they can spend to pay for pressing needs in the university. Before such finds can be released, the issue of administrative bottleneck becomes the order of the day (Kingdon and Teal, 2010).

\section{Shortfall in budgetary allocation to education (university education)}

Another major cause of industrial actions by university lecturers is the shortfall in budgetary allocation to the education sector by the Nigerian government. The United Nations and other international organizations pegged budgetary allocation to education to be at $26 \%$ of the entire country's budget, but since the return of democracy or even before that time, education in Nigeria has not received beyond $13 \%$ and it keeps dwindling year in year out. Thus the amount of funds released from the paltry budget that goes to the university hardly can solve the infrastructural need of the universities. Lecturers are expected to bring it the most in terms of their productivity, but would they provide this utmost productivity with their hands and mouth? (Spaull, 2013).

Lecturers embark on industrial action to draw government and other stakeholder's in education attention to the havoc their budgetary allocation to the education sector is brining on the nation's ivory tower. This is to force government reverse their position and improve their funding of education. Unfortunately, the government since then had done practically nothing to help improve the funding to university education in Nigeria (Taylor, 2011).

\section{Revitalization of Nigerian universities}

It is unfortunate to state that since 2013, a total of \#1.3 Trillion was budgeted for education by the agreement entered into willingly by Nigerian government and ASUU, but till today, \#605 Billion is still hanging, while government in 2017 agreed to pay \#20 Billion every quarter to the universities from 2017 to 2018, to defray the debt owed from 2009-2013, and then renegotiate from 2014-2019, but unfortunately, no kobo has been given to ASUU after the initial \#20 Billion to resume schools. ASUU went again on another strike in 2018 November, to December, and yet again nothing came out of that strike. But the students were the worst hit as they came back hurriedly and began their first semester with very short time to complete the semester. The school curriculums have been jam packed for the students and the time has been shortened from 16 weeks to 8 weeks to complete the semester (Van der Berg, 2008).

\section{9 and 2013 ASUU-FGN Agreement}

ASUU frowns at the federal government's inability to keep to the terms of the 2009 and 2013 agreements which it voluntarily entered into with ASUU. Part of the terms of the agreement in which government has defaulted include payment of staff entitlements since December, 2015, funding of universities for revitalization, pension, TSA and university autonomy and renegotiation of the 2009 agreement. Outside these agreements, the 2013 Memorandum of Understanding (MOU) was again entered into between ASUU and the federal government of Nigeria; this again was defaulted by the government. The 2017 Memorandum of Implementation again entered into by ASUU and the Federal Government of Nigeria, this again was defaulted by government, hence the November, 2018 industrial action (World Bank, 2010).

There are other subtle causes within the university system which has necessitated industrial actions. When lecturers embark upon industrial actions, it is not always against government, at times, it is against the university management, where staff salaries, promotion arrears. Honoraria and other entitlement for lecturers are denied. These could also lead to industrial actions within the school system. When lecturers embark on industrial action as often as they do, the effects are numerous, ranging from student's engagement in antisocial vices, robbery, prostitution, kidnapping, cultism, poor implementation of the university mandates of teaching, researching and community services, poor curriculum content coverage, shortened academic calendar, production of half baked, half cooked graduate with paper qualification without commensurate technological knowledge to contribute to 
national development and global competitiveness, poor academic performance by university undergraduate students, lack of effective productivity by university lecturers and above all, delay in graduation period for prospective university graduates (Zwerling, 2008).

The role of universities in human capital development, research and technological innovation cannot be under evaluated. Nations today depend increasingly on knowledge, ideas and skills which are produced through researches in the universities. Nations invest in university education because society expects it to contribute to national development in three principal ways. First, society expects its university to produce the highly skilled personnel in technology, engineering, management and other professions; secondly, universities have the responsibility of producing their own corps of academic personnel that is, the intellectual resource pool that will, through scientific research generate new knowledge and innovation to solve developmental problems. Thirdly, universities produce teachers, administrators and managers for other levels of human resources development institutions (Zwerling, 2008).

The rate of incessant strike actions in the country has been a source of concern to all stakeholders of education, because of the effects on students who are totally seen to be at the receiving end of every strike action, because it affects their academic advancement. Although lecturers are entitled to go on strike when their condition of services and other demands are not granted by government who are their employers, but extended industrial action is usually not considered unfavorable to students. The disagreement or lack of understanding between government and the academic staff often results in dead lock that usually disrupts student's academic calendar, thereby increasing the year of graduation for the students. Arising from the foregoing, does lecturer's industrial action really produced the desired result for lecturers? What are the effects of these incessant lecturers's industrial action on student's academic performance in the department of Environmental Education in the University of Calabar? This research therefore intends to fill this gap.

Three research questions and commensurate null hypotheses were formulated for the study thus:

a. What are the persistent causes of lecturer's industrial actions?

b. To what extent does lecturer's industrial action affect school curriculum content coverage and academic calendar?

c. How does lecturer's industrial action influence student's academic performance in Environmental Education in the University of Calabar?

\section{Research methods}

The research design adopted for this study is the survey inferential research design, this method allow a representative fraction of the entire population to be selected and used for an in-depth study, so that result produced can be used for a valid generalization about the entire population of the study. The study area is the University of Calabar, University of Calabar lies between Calabar South and Calabar Municipality Local Government Areas of Cross River State. University of Calabar lies between latitude $04.15^{\circ}$ and $5.5^{\circ} \mathrm{N}$ and longitude $8^{0} 25^{\prime} \mathrm{E}$ of the Greenwich Meridina. Calabar is bounded in the North by Odukpain LGA, in the south, it is bounded by Akpabuyo and the Great Cakabar river, while in the South, it is bounded by the Kwa river and Atlantic ocean and in the East, Calabar is bounded by Akamkpa and some part of Akpabuyo local government area.

The University of Calabar has 14 faculties, 3 institutes and four research centers. The department of Environmental Education is domiciled in the faculty of education, which is one of the mother faculties with 13 departments in the University of Calabar. The University of Calabar, was a campus of the University of Nigeria, Nsukka, it became a full fledge university in 1975, but full academic program began in the university from the Duke Town Secondary School in 1976 with three faculties. The department of Environmental Education became a full stand alone department in 2013/2014 academic session from the department of Curriculum and Teaching. Though the program started as far back as 1992, with the introduction of ordinary diploma in Environmental Education and Post graduate Diploma in Environmental Education, then domiciled in the Institute of Education.

It was moved to Curriculum and Teaching when it began the running of degree program. The department has two streams of students, the National University Commission (NUC) regular program and the University of Calabar non regular or part time program. The NUC program has teaching subjects as their areas of specialization, but in recent times, because of the introduction of Tourism Education in secondary schools, all Environmental Education students in the NUC regular program offer tourism education as their area of specialization. While the non NUC program popularly called the Center for Educational Services (CES) program have five areas of specializations: Tourism and Eco-management (ETE), Pollution and Waste Management (EPW), Forestry and Wildlife Resources Management (EFW), Gender Studies (EWE), Community Environmental Services (CES) and Population and Environment (EPR).

The population of the study consists of all the students and lecturers in the department of Environmental Education. There are a total of 489 students at the undergraduate level, 96 Master's degree students and 23 lecturers. The sampling technique adopted for the selection of samples for the study is the stratified and systematic random sampling techniques. This was used to select a sample of 250 students and lecturers for the study. The 
instrument for data collection is a researcher structured questionnaire designed in two sections, A gives information on respondent's socio-demographic characteristics, while section B elicits response on the variables under study. The researchers personally administered the instruments and collected same back, there was $100 \%$ return rates. The Pearson Product Moment Correlation Analysis was used to test the hypothesis formulated for the study.

\section{Results and discussion}

What are the persistent causes of lecturer's industrial action in the universities?

From the result of the simple percentage analysis on table 1 showing the causes of persistent lecturer's industrial actions in Nigerian universities, 168 respondents representing $67.1 \%$ agreed that the causes listed on table 1 are responsible for persistent lecturer's industrial actions, while 82 respondents, representing $32.9 \%$ disagreed that the causes listed above on table are not responsible for the persistent lecturer's industrial actions. From this result, it has been established that poor salaries and remunerations, poor condition of service and near absence of staff development programs, near absence of research grants to staff, poor office spaces and accommodations, poor classrooms conditions /lecture theater, poorly stocked libraries/ old materials, poor laboratory/workshops and studios, staff promotion/ motivation, shortage of infrastructure and other facilities and poor relationship between management and lecturers.

Table 1: Respondent's opinion of the persistent causes of lecturer's industrial action in the universities

\begin{tabular}{llcccc}
\hline No & Causes of persistent lecturer's industrial actions & Agree & $\%$ & Disagree & $\%$ \\
\hline 1 & Poor salaries and remunerations & 184 & 73.6 & 66 & 26.4 \\
2 & Condition of service/ Staff development programs & 199 & 79.6 & 51 & 20.4 \\
3 & Near absence of research grants to staff & 169 & 67.6 & 81 & 32.4 \\
4 & Poor offices spaces and accommodations & 200 & 80 & 50 & 20 \\
5 & Poor classrooms conditions /lecture theater & 199 & 79.6 & 51 & 20.4 \\
6 & Poorly stocked libraries/ old materials & 201 & 80.4 & 49 & 19.6 \\
7 & Poor laboratory/workshops and studios & 178 & 71.2 & 72 & 28.8 \\
8 & Staff promotion/ motivation/bonuses & 215 & 86 & 35 & 14 \\
9 & Shortage of infrastructure and other facilities & 234 & 93.6 & 16 & 6.4 \\
10 & Poor commitments on the side of the lecturers & 35 & 14 & 215 & 86 \\
11 & Poor relationship between management and lecturers & 187 & 74.8 & 63 & 25.2 \\
12 & Default on the part of government to implement agreements signed & 12 & 4.8 & 238 & 95.2 \\
& lecturers are self centered and greedy & & & & \\
13 & Default on the part of government to implement agreements signed & 184 & 73.6 & 66 & 26.4 \\
& Total & 2013 & & 987 & 250 \\
& & 168 & 67.1 & 32.9 & 100 \\
\hline
\end{tabular}

Others cause like poor commitments on the side of the lecturers and because lecturers are self centered and greedy; 35 respondents (14\%) and 12 respondents (4.8\%); were rejected as causes of persistent lecturer's industrial action. One would expect that since there are always persistent industrial actions, it is assumed that lecturers are always embarking on these industrial actions for their personal gains and benefits. This was traced to blaming lecturers for being self centered and greedy, however the response presented by the respondent's from the field, proofed otherwise. 12 respondents representing $4.8 \%$ ticked that the major causes of industrial actions are caused by the lecturers as a result of the their being self centered and greedy to make government meet their personal desires instead of considering the students, whereas 238 respondents $(95.2 \%)$ strongly disagreed that it is not because of lecturers' greed and self centered disposition that lecturers go on persistent industrial actions, while 184 respondents $(73.4 \%)$ ticked that lecturers go on strike because the government had always defaulted in the implementation of agreements reached with ASUU, while 66 respondents (26.6\%) disagreed that this is not the reason why lecturers go on industrial actions, but a combination of several other factors as listed on the result sheet. It is worthy however to mention that the factors which have been mentioned on the result sheet, if reduced, it boils down to the major five reasons adduced for the persistent strike actions by the university lecturers of lack of bonuses, entitlement and remunerations, university autonomy, lecturers salaries and wages among others.

The implication of this result is that, when lecturers embark on persistent industrial actions, these industrial actions hinder the coverage of the university curriculum content. This is seen on the extent to which topics which have been arranged to cover 12 weeks are hurriedly suffocated into shorter periods of time. This is not good enough for the learners who are always over loaded with stuff for meant for a longer period of time. This finding is in line with the earlier finding of Adibe, (2009) who found that when industrial actions are embarked upon by university lecturers, there is a $95 \%$ probability that there must be a shift in the school academic calendar, where curriculum contents are hardly covered or completed. In most scenarios, students are forced to complete a curriculum that would have ordinarily been completed in 6 months; students are forced to cover them in 2-3 months. This brings so much academic stress on the student and also the lecturers. 
In worst case scenario, the students are overloaded with academic workload that they hardly have time to concentrate, in some cases; these students prefer to copy from their friends to going all out to do their assignment themselves. This is a confirmation of the finding of Ivancevich, (2007) who found that during industrial actions, students are left at the mercy of their fate, and after the strike actions, students are over loaded with stuff that would have been taught over a given period of time. Here, the author observed that students are over fed with academic stuff and lecturers may not have the time to check whether what they are teaching the student, the can accommodate given their circumstance at the materials time or not. Michael, (2013) earlier result also brought more credence on the finding of this particular study, the author posited that strikes or lecturer's industrial action are issues that has affected the coverage of university curriculum content and academic calendar in most universities. It is on the basis of this that most universities in Nigeria are running different academic calendars, some begin by January and end in September, while others begin in March and end in December, while others still begin from May and end up in February. These hap hazard academic calendars are as a result of the industrial actions embarked upon by most universities, especially those under the umbrella of Academic Staff Union of Universities (ASUU) and other sister trade unions in the universities.

Question two: To what extent does persistent lecturers' industrial action affect curriculum content coverage and academic calendar?

Based on the data extracted from the questionnaire and analyzed using the simple percentage analysis, 199 respondents, representing $79.6 \%$ of the respondents agreed that lecturer's persistent industrial action affects curriculum content coverage, while 51 respondents' representing $20.4 \%$ disagreed that persistent lecturer's industrial action does not significantly affect university curriculum content coverage. The implication of this simple percentage analysis indicates that when industrial actions are embarked upon by lecturers in the universities, their curriculum content coverage is hindered, because the students would be taught under short and compacted program duration. In teaching and learning in such shortened period, curriculum meant for six months might be forced to be covered in a month or weeks. Under this situation, slow learners are usually on the hit, while the curriculum is seldom covered. The academic calendar is also abridged leading to leaving most curriculum content and other co-curricular activities which the students were ordinarily supposed to do to be left undone.

According to Ige, (2013) is a duration of time marked by the university for the execution of its activities over a period of time, normally academic calendar is spread over a whole year, divided into two semesters of six months each. Usually, course works, lectures, assignment, examinations and holidays are all included within this academic calendar. According to international best practices, academic calendars are university time table or schedule of duties where every activity in the university system is outlined with timeline attached for every member of the university to follow.

Since it has been established that industrial actions are all actions taken by labor unions to press home their demand for a better condition of service in order to improve productivity and efficiency within any organization, these include work to rule, stay at home, avoidance of work etc. When industrial actions are embarked upon, most often than not, a better chunk of university academic calendar is spent away from duty post, once this happens, works are abandoned, duties are not performed over the period they were supposed to cover or take, then there is a lag period. Once this occurs, and immediately after resumption from such industrial actions, the university begins to look for every avenue to enable them manage the lost time by suffocating students with overloaded work over a very short period of time, in this case, a crash program is employed to make sure students write their exams after a thoroughly compressed academic program.

This finding is in line with the finding of Ivancevich (2007); Ladokun, (2005) and Armstrong (2004), who found that generally once industrial actions occur in any establishment, there is bound to be time lag, and once this happens, lecturers are forced to work under pressure to cover their academic calendar, while students are usually over fed with their academic activities, leading to stress and fatigued in the course of trying to cope with the overloaded and crowded program which had naturally been crashed to meet the limited time frame available for the program. This result is also a confirmation of the finding of Wilson, (2005) and Adeyemi, (2010), who posited that generally, industrial actions embarked upon by staff of any organization are usually unproductive, it brings about productivity differentials, reduce staff production capacity leading to inefficiency in staff work capacity. Here, the organization stands to lose as it must meet their demands and at the same time count their losses in terms of productivity and efficiency.

In the University of Calabar, as the case is currently going on, lecturers are in a hurry to catch up with the academic calendar for 2018/2019 session. Academic session was supposed to have resumed since January for this session, but because of the industrial action embarked upon for the non compliance and implementation of the ASUU/FGN agreement of 2009, the 2013 Memorandum of understanding (MOU) between ASUU/FGN and the 2015 Memorandum of implementation (MOI), it is now a jam packed schedule of activities, both lecturers and students are now put on their toes to make sure the academic calendar is covered, whether by crashed program or whatever means. The backlash of this marathon academic program delivery falls directly on the students and their guardians or parents. 
Lecturers want to cover their curriculum, the school wants to cover their academic calendar and the students must be ready to receive whatever the school or institution must put on them in terms of the burden of implementation of the school programs. In many cases, students become depressed, fatigued and stressed beyond their limit. In some cases, students just sit for examination which they are ill prepared for just to satisfy all righteousness. One can then understand why most products of Nigerian universities are half baked, half cooked, with paper qualifications without commensurate knowledge to contribute to national development in terms of technical knowhow.

Question 3: How does lecturer's industrial action influence student's academic performance in Environmental Education in the University of Calabar?

Table 2: Some effects of lecturer's industrial action on student's academic performance

\begin{tabular}{|c|c|c|c|c|c|}
\hline & $\begin{array}{l}\text { Effects of industrial action on student's academic } \\
\text { performance }\end{array}$ & Agreed & $\%$ & \multicolumn{2}{|c|}{ Disagreed \% } \\
\hline 1 & Hap hazard teaching and learning & 177 & $(70.8)$ & 73 & $(29.2)$ \\
\hline 2 & Lack of curriculum coverage & 186 & $(74.4)$ & 64 & $(25.6)$ \\
\hline 3 & Constriction or extension of academic calendar & 169 & $(67.6)$ & 81 & $(32.4)$ \\
\hline 4 & $\begin{array}{l}\text { Put too much academic stress on students who are forced } \\
\text { to cover what they would have covered in } 6 \text { months in less } \\
\text { than three months }\end{array}$ & 199 & $(79.6)$ & 51 & $(20.4)$ \\
\hline 5 & Poor performance in student's result & 181 & $(72.4)$ & 69 & $(27.6)$ \\
\hline 6 & Delay in student's graduation & 172 & $(68.8)$ & 78 & $(31.2)$ \\
\hline 7 & Production of half baked quack graduates & 188 & $(75.2)$ & 62 & $(24.8)$ \\
\hline 8 & $\begin{array}{l}\text { Graduating students with paper qualification without } \\
\text { commensurate knowledge }\end{array}$ & 190 & $(76.0)$ & 60 & $(24.0)$ \\
\hline 9 & $\begin{array}{l}\text { Poor technological knowledge which cannot support the } \\
\text { country's technological development needs }\end{array}$ & 195 & $(78.0)$ & 55 & $(22.0)$ \\
\hline 10 & Encourages school drop outs & 187 & $(74.8)$ & 63 & $(25.2)$ \\
\hline 11 & Bring more problems on students funding & 179 & $(71.6)$ & 71 & $(28.4)$ \\
\hline 12 & Encouraging social vices among students & 189 & $(75.6)$ & 61 & $(24.4)$ \\
\hline 13 & $\begin{array}{l}\text { Death and deformity among students who travel due to } \\
\text { strikes }\end{array}$ & 200 & $(80.0)$ & 50 & $(20.0)$ \\
\hline & Total & 2412 & & 838 & \\
\hline & 3250 & $74.2 \%$ & & $25.8 \%$ & \\
\hline
\end{tabular}

From the simple percentage analysis on table 2, thirteen items were listed as the effects of lecturer's industrial action on student's academic performance, about 185 respondents representing $74.2 \%$ of the respondents agreed that these are some of the effects of lecturer's industrial action on student's academic performance, while 65 respondents representing $25.8 \%$ of the respondents disagreed that these are not the effects of lecturer's industrial action on student's academic performance in the department of Environmental Education in the University of Calabar. Since the percentage of those who agreed (185 respondents, $74.2 \%$ ) are far higher than the percentage of those who disagreed, $(65,25.8 \%)$, those who agreed listed the above effects as the effects of lecturer's industrial action on Environmental Education student's academic performances in the University of Calabar, Nigeria.

This effects are not only limited to students, but also on staff who are on the struggle, a practical example is the death of the former national president of ASUU, Prof. Festus Iyayi who died in a ghastly motor accident to the convoy of the former governor of Kogi State and two other lecturers who died along Abuja-Lafia during a national assignment during the course of their struggles. These brains have been lost and lost forever.

To further give credence to the data used to give more information, a hypothesis was tested to see how lecturer's industrial action influences Environmental Education student's academic performance. The result of the Pearson Product Moment Correlation Analysis of the relationship between lecturer's industrial actions and student's academic performance in Environmental Education in the University of Calabar is shown on table three. Table 3: Pearson Product Moment Correlation Analysis of the relationship between lecturer's industrial action and student's academic performance in Environmental Education $(\mathrm{N}=250)$

\begin{tabular}{lllll}
\hline Variables & $\mathrm{X}$ & $\mathrm{SD}$ & $\mathrm{R}$ & Sig. (2-tailed) \\
\hline Lecturer's industrial action & 11.52 & 2.91 & &
\end{tabular}

Student's academic performance in $11.92 \quad 3.45$ Environmental Education

*Significant at $.05, \mathrm{r}$-calculated $=0.74^{*}, \mathrm{r}$-critical $=0.136, \mathrm{df}=248$

The result of the analysis presented in Table 3 revealed that lecturer's industrial action significantly influences student's academic performance in Environmental Education in the University of Calabar $(r=0.74 ; \mathrm{p}<.05)$. This 
is so because the calculated (r) value of 0.74 is higher than the critical r-value of 0.136 at .05 level of significance and 248 degree of freedom, the null hypothesis which stated that there is no significant relationship between lecturer's industrial actions and students' academic performance in Environmental Education is rejected while the alternate hypothesis which states there is a significant relationship between lecturer's industrial actions and students' academic performance in Environmental Education is now accepted. The implication of this result is that lecturer's industrial actions significantly influence students' academic performance in Environmental Education.

The result on table 4 shows means results of Environmental Education students from 2013-2018 before and after industrial actions embarked upon by lecturers. From the result, between 2013-2018, students scored different grades, this is averaged in scores of different classes, which is then added year by year and the average of students from 100 level to four and five hundred levels respectively were again calculated per session. From this result, before the strike in 2013, the average score for the session was $67.8 \%$, while after the strike, the average score was 56.8 , the difference was $11 \%$ decline in student's grade. Same was the case in all the years except in 2016 , where there was no industrial action embarked upon by academic staff which had a negative difference.

Table 4: Test scores for academic performance of Environmental Education Students before and after industrial actions from 2013-2018

\begin{tabular}{|c|c|c|c|}
\hline \multicolumn{4}{|c|}{ Percentage ${ }^{\circledR}$ examination scores of Environmental Education students from 2013-2018 } \\
\hline Before strike & & After strikes & Difference \\
\hline 2013 & 67.8 & 56.8 & 11 \\
\hline 2014 & 62.9 & 60.1 & 2.8 \\
\hline 2015 & 71.3 & 70.7 & 0.6 \\
\hline 2016 & 65.5 & 66.8 & -1.3 \\
\hline 2017 & 77.5 & 59.8 & 17.7 \\
\hline 2018 & 70.6 & 60.2 & 10.4 \\
\hline Total & 415.6 & 374.4 & 41.2 \\
\hline Mean & 69.3 & 62.4 & 6.9 \\
\hline Difference & & & \\
\hline
\end{tabular}

The mean student's scores before lecturer's industrial action (between 2013-2018) was 69.3\%, while the same score after the lecturer's industrial action was $62.4 \%$ indicating a difference of $6.9 \%$ decline in student's academic performance. From this result, it is possible that lecturer's industrial action has affected student's academic performance in the department of Environmental Education in the University of Calabar. It is also possible, that there are other factors which must have contributed to this decline in student's academic performance in Environmental Education, but the concern of this research is that lecturer's industrial action has influenced student's academic performance ion Environmental Education in the University of Calabar.

The extent to which students have the resilience to cope and graduate from the university system with these persistent strikes is determined by the student's ability to withstand pressure and fatigue from the crash programs meted out on them. The result of the analysis shows that the respondents listed the following as being the effects of lecturer's industrial action on student's academic performance thus: haphazard teaching and learning, lack of curriculum content coverage, constriction, compression or extension of academic calendar, putting too much pressure on students who are forced to cover what they would have ordinarily covered in 6 months in less than two months. The result further listed poor performance in student's semester results, delay in graduation period, production of half baked, half cooked graduates with practically nothing to contribute to national development.

Other effects include graduating students with paper qualification, without commensurate knowledge, poor technological knowledge which cannot support national technological development. The researcher and their respondents also posited that lecturer's industrial action also encourage school drop outs, bringing more problems on the student, social vices become heightened among students and death and deformity may also occur when students travel to and from their homes because of the persistent industrial action embarked upon by lecturers.

In Environmental Education in the University of Calabar, the same applies; most graduates are forced to graduate years after their normal period of graduation. It has become a popular dictum in Nigerian universities, Unical inclusive, that in Nigeria, you only know when you are admitted into the institution, but your year of graduation is dependent on lecturer's persistent strikes. Therefore lecturer's industrial actions affect student's academic performance in terms of quality, efficiency and graduation.

In terms of quality, Amadi; (2015); Ibayi, (2006)and Mariga, (2007) posited that when students are put under pressure to study, it affects their concentration and learning, especially when the teaching and learning process is under duress. The student's capacity to accommodate new ideas with such speed and stress becomes limited, in most cases, as new knowledge is downloaded on the students, the learning retention capacity diminishes with more and more download from the lecturers.

There is also the tendency that the students will only study to pass the examination, no longer for knowledge sake, but for examination sake. This takes us back to education for paper qualification and not for knowledge sake.

In terms of efficiency and productivity, there is always a dictum that said you cannot give out what you do 
not have, when students are graduated under these crash programs, they are not properly grounded in their course of study, when sent out to work in the field they studied, they can only manage to function minimally, not optimally, especially if they are sent to teach in schools or other institutions of learning. Here effectiveness and efficiency are hampered by these crops of graduates. There is also the period of graduation set by the university for students to graduate from the system, when lecturers embark on industrial actions, some may take like a whole year, others beyond that and in some cases shorter period.

Like the 2013 ASUU industrial action, it took a complete year for them to be called back on campus, almost all the students in the universities that year had to spend one extra year before graduation, those who were supposed to participate in the compulsory National Youth Service (NYSC) program could not because they had additional year to their age, some became above the 30 years maximum requirement. Some who were on study leave with a fix period had to abandon their program for want of time. These and many others are the situation where lecturer's industrial actions affect Environmental Education student's academic performance in the University of Calabar and other universities where persistent strike actions occur.

\section{Conclusion}

In the education sector, industrial actions by academic and non academic staffs can lead to students' examination malpractice, corruption and other social vices in the society. Strike is a social ill not different from corruption because it eats into students' time which makes it difficult for students to be fully and properly 'baked' within the designated education time frame. As a result, 'products' that are ill-equipped both in character and learning are turned out to the society and hardly can they contribute any meaningfully to national development. Based on the result of data analyzed and the finding of the study, it is therefore concluded that lecturer's industrial actions significantly influence university academic calendar and curriculum content coverage and also has a significant influence on student's academic performance in Environmental Education in the University of Calabar, Nigeria.

\section{Recommendations}

a. It is true that government has defaulted severally in the implementation of the agreements and memorandum of understanding and implementation it voluntarily entered into with ASUU, it is incumbent on ASUU to take a stand, go on one industrial action, refused to resume until all the necessary infrastructures, revitalization and improved condition of services including their remuneration, bonuses and entitlements are paid to them before resuming, by so doing, government will meet their basic requirement, so that once they resume, there will be no need for any persistent industrial actions in the universities. A good example is the universities in Ghana, today, most Nigerian government functionaries send their children to school in Ghana instead of repairing our own universities.

b. Government should as a matter of urgent public interest, provide monies to the universities and also improve their condition of services with functional libraries, laboratories and office spaces to enable lecturers bring out their best in terms of productivity and effective and efficient service delivery.

c. Private individuals and organizations should partner with the university to provide research grants to staff to assist them carry out ground breaking researches that can contribute to the growth of the private sector and also national development

d. Companies like Dantata, Dangote, Niger mills, etc should contract university lecturers in different fields to carry out researches on the best way to provide improve raw materials which they use for the production of their flowers, they can also use their biotechnology skills to cross breed different varieties of fast growing and high yielding species to carter for the domestic needs of these industries instead of paying heavily to import their raw materials.

e. Universities should also allow lecturers free hands to do contracts within the universities and also act as guarantors to their lecturers to pursue and execute government and private contracts; this will attract additional revenue to the universities and to the lecturers.

f. Government should provide research grants to university lecturers including the cost of publication of such research outcomes. This will encourage the lecturers to go all out to do more for the universities.

g. Private establishment can also allow lecturers to carry out free laboratory analysis in their facilities, this will go a long way to bridge the gap between what the government, universities and individuals can provide to help the university system grow well and compete favorably with other countries of the world.

h. Technocrats from the universities should be selected and given appointment to head educational institution since they know what the universities want.

\section{References}

Adibe, J. (2009). ASUU and the Politics of the Stomach. Retrieved from Tribune 27th June.

Altinok, N. and Kingdon, G. (2012). 'New Evidence on Class Size Effects : A Pupil Fixed Effects Approach', Oxford Bulletin of Economics and Statistics; 74(2): 203-234. 
Ayeni, O. G. and Kolawole, O. (2014). The Incessant Conflicts and Strikes and their Effect on the Achievement of Goals of Business Education In Tertiary Institution in Ekiti State. .......

Baker, M. (2011). Industrial Action in Schools: Strikes and Student Achievement. NBER Working Paper Series No.16846, Cambridge, Massachussets: National Bureau of Economic Research, Available: http://www.nber.org/papers/w16846 [May 2013].

Belot, M. and Webbink, D. (2010). Do Teacher Strikes Harm Educational Achievement of Students?', Labour; 24(4): 391-406.

Chisholm, L. (1999). 'The Democratization of Schools and Politics of Teachers' Work in South Africa', Compare: A Journal of Comparative and International Education; 29(2):111-126.

Clotfelter, C.T., Ladd, H.F. and Vigdor, J.L. (2009). Are Teacher Absences Worth Worrying About?', Education Finance and Policy; 4(2): 115-149.

Edinyang, S. D. and Ubi, I. E. (2013). Effect of Strike Action on Human Development among Social studies Secondary School Students in Uyo Local Government Area of Akwa Ibom State, Nigeria. Global Journal of Human Resource Management; 1(2): 1-8

Freier, R. and Storck, J. (2012). The Treatment Effect of Attending a High-Quality School and the Influence of Unobservables, Berlin: German Institute for Economic Research (DIW Berlin), Available: http://ssrn.com/abstract=2197847 [1 July 2013].

Ige, A. M. (2014). Towards the Stemming of the Tide of Strikes in Tertiary Institutions in Nigeria: Stakeholders' Roles and Responsibilities. European Journal of Academic Essays 1(7): 18-26, www.euroessays.org.

Ivancevich, J. M. (2007). Human Resources Management (10thed.) McgrawHill, International Edition, Singapore.

Kingdon, G. (2006). Teacher characteristics and student performance in India: A pupil fixed effects approach, Global Poverty Research Group Working Papers GPRG-WPS-059.

Kingdon, G. and Teal, F. (2010). Teacher unions, teacher pay and student performance in India: A pupil fixed effects approach', Journal of Development Economics; 91: 278-288.

Michael, B. (2013). Industrial Action in Schools: Strikes and Student Achievement. Canada Labour Market and Skill Researcher Network. CLSRN Working Paper No. 111.

Olupayimo, E. O. (2014). An Examination of the Impact of Incessant Strikes on Skills Acquisition in Business Education. Association of Business Educators of Nigeria. Compiled Journal Articles.

Osuorji, A. N. and David, S. (2014). The Effect of Incessant Strikes on Academic Performance of Business Education Students In Abu, Zaria. Association of Business Educators of Nigeria.

Ricarda, S., Anja M., Anne F. W., and Linda W. (2014). Oxford Bibliographies Academic Achievement http://www.oxfordbibliographies.com/view/document.

Saharay, H. K. (2013). Textbook on labour \& Industrial Law, fifth edition. Universal Law Publishing Co, New Del

Spaull, N. (2013) 'Poverty and Privilege: Primary School Inequality in South Africa', International Journal of Educational Development, vol. 33.

Taylor, S. (2011) Uncovering indicators of effective school management in South Africa using the National Schools Effectiveness Study, Stellenbosch Economic Working Papers: 10/11.

Van der Berg, S. (2008) 'How effective are poor schools? Poverty and educational outcomes in South Africa', Studies in Educational Evaluation; 34: 145-184.

World Bank (2010) Africa Development Indicators 2010: Silent and Lethal - How quiet corruption undermines Africa's development efforts, Washington, Available: http://siteresources.worldbank.org/AFRICAEXT/Resources/english_essay_adi2010.pdf [July 24 2013]. 37

Zwerling, H.L. (2008) 'Pennsylvania Teachers' Strikes and Academic Performance', Journal of Collective Negotiations; 32 (3): 151-172. 